\title{
Tourism-Led Growth Hypothesis in Mediterranean Countries: Evidence from a Panel Cointegration and Error Correction Model
}

\author{
Banu Demirhan ${ }^{1}$ \\ ${ }^{1}$ Afyon Vocational School, Department of Economics and Administrative Programs, Afyon Kocatepe University, \\ Afyonkarahisar, Turkey. \\ Correspondence: Banu Demirhan, Afyon Vocational School, Department of Economics and Administrative Programs, \\ Afyon Kocatepe University, Afyonkarahisar, Turkey.
}

Received: November 13, 2015

Accepted: November 18, $2015 \quad$ Available online: November 23, 2015

doi:10.11114/aef.v3i1.1207

URL: http://dx.doi.org/10.11114/aef.v3i1.1207

\begin{abstract}
Today, there is a consensus on the contribution of the tourism sector to the economy in Mediterranean countries, which have a significant share in the world tourism. The objective of this paper is to investigate and estimate the effect of the tourism sector on economic growth in Mediterranean countries. This paper employs panel FMOLS and panel DOLS models using data consisting of nine Mediterranean countries over the period 1995-2014. Empirical findings indicate that tourism receipts and tourism arrivals affect economic growth positively in the long-run and that these results are valid as individually, which shows tourism-led growth hypothesis is valid in Mediterranean countries.
\end{abstract}

Keywords: tourism receipts, Mediterranean countries, FMOLS, DOLS

\section{Introduction}

The tourism sector has today become one of the most important industries in the world, and policy makers have strived to develop this sector because of its contributions to the economy. According to UNWTO (2015), the number of international tourists reached 1,138 million in 2014 with an increase of 51 million or a $4.7 \%$ increase over the previous year. It is expected to grow by $3 \%$ to $4 \%$ in 2015 . Moreover, receipts in destinations from international tourism reached US\$ 1,197 billion in 2013. When considered that the dollar value of world merchandise exports in 2013 was US\$ 18.8 trillion (WTO, 2014), the importance of tourism receipts in World economy can better understood. Tourism sector provides the economy with foreign exchange earnings such as exports. This fact is the primary source of its positive effect on the economy and the basic rationale of being considered of the tourism sector by both policy-makers and researchers. The tourism sector has become more important for developing countries because its social cost and benefits should be considered when policymakers create tourism policies (Iwersen-Sioltsidi \& Iwersen, 1996). In developing countries, also, the tourism sector is regarded as an additional factor to conventional factors such as capital formation, exports, and human capital for economic growth.

Tourism Sector has a positive impact on economic growth in several ways. First, tourism earnings provide foreign exchange income for the import of capital goods and thus contribute to economic growth (McKinnon, 1964). In other words, tourism sector facilitates the finance of the import of capital goods that are used for the goods produced in the country. Second, the advances in tourism sector create some exogenous benefits for other sectors, such as agriculture, manufacturing, service, and soon; therefore it would bring out a multiplier effect in the economy. For instance, some products and services used in the tourism sector are provided from other sectors, and the developing in tourism sector increases the production in these sectors, increasing domestic demand and economic growth. It is worth noting that tourism incomes distributed among production factors would create additional spending in the economy, contributing to economic growth. Third, tourism sector helps small countries to compete with large countries. Although small economiesare considered in a disadvantageous position in the global competition, they can surpass larger economies, implying that the smallness of scale is not fatal to prosperity (Vanegas \& Croes, 2003). In this context, tourism sector enhances the competitiveness of small economies by channeling tourism earnings to productive investment opportunities. Fourth, tourism earnings decrease current account deficit, which may increase when an economy grows and is one of the main problems in developing countries. Therefore, the link between current account deficit and economic growth becomes weak. Fifth, tourism sector decreases the unemployment rate by creating new job areas and 
thus provides extra income contributing to the economic growth. Sixth, tourism sector allows smaller scale firms to create large benefits to the local economy (Andriotis, 2002; Schubert et al. 2011).

An empirical finding on a positive contribution of tourism income to economic growth is known as tourism-led-growth hypothesis and is referred to unidirectional causality from tourism income to economic growth in econometric jargon. Indeed, the tourism-led growth hypothesis is directly derived from the hypothesis considering exports as a driver of the economic growth. In the context of the new growth theory developed by (Balassa 1978), exports and tourism have a positive effect on economic growth either through improving the allocation of production factors or expanding the sources (Brida et al., 2015). Reviewing the empirical literature, we notice that different findings have been obtained in previous studies; the reason of which can be different time periods and econometric methods used in these studies. The empirical findings and time periods used in previous studies on Mediterranean countries are shown in Appendix A. In the empirical literature; various econometric methods have been used to investigate the relationship between tourism income and economic growth. Some studies investigated the relationship for specific countries, using standard time-series methods (e.g. Eeckels et al. (2012) and Dritsakis (2004) for Greece; Ongan \& Demiroz (2005), Arslantürk \& Atan (2012), Gökovalı (2010), Arslantürk et al. (2011), Hüsein \& Kara (2011), Gunduz \& Hatemi (2005), Kaplan \& Çelik (2008), Katırcıoğlu (2009a), Zortuk (2009); Öztürk \& Acaravcı (2009) for Turkey; Merida \& Golpe (2014), Balaguer \& Cantavella-Jorda (2002), Nowak et al. (2007) for Spain; Cortes-Jimenez et al. (2011) and Belloumi (2010) for Tunisia; Tang \& Abosedra (2014) for Lebanon; Massidda \& Mattana (2013) for Italy; Cortes-Jimenez \& Pulina (2010), for Spain and Italy; and Katırcioğlu (2009b) for Malta.Some studies used panel data method to investigate tourism led growth (e.g. Tuğcu, 2014; Aslan, 2014; Santana-Gallego et al., 2011; Al-Mulali et al., 2014; Dritsakis, 2012; Lee \& Chang, 2008; Chou, 2013; Cortes-Jimenez, 2008; Holzner, 2011; Nissan et al., 2011; Caglayan et al., 2012; Ekanayake \& Long, 2012; Gökovalı \& Bahar, 2006; Saleh et al.,2015). Moreover, a few studies using cross-section method are available (e.g. Po \& Huang, 2008). It is worth noting that Brida et al. (2014) provide a comprehensive literature including various countries

The aim of this study is to investigate the effect of the tourism sector on economic growth in Mediterranean countries, in which tourism sector has an important contribution to national economies. This paper contributes to the literature in two ways. First, although export-led growth hypothesis has been investigated extensively in the literature, there are not many studies that empirically examine the tourism-led growth hypothesis (Tang \& Abosedra, 2014). In the existing studies analyzing the effect of the tourism sector on economic growth in the empirical literature, the number of the studies focusing on Mediterranean countries is less. Second, time-series analysis is frequently used in the empirical literature as seen in Appendix A. On the other hand, we use modern panel techniques to estimate coefficients, allowing us to compare them with the previous studies in which different econometric techniques were used.

The rest of the paper is organized as follows: In the next section, we present an overview of the tourism sector in the Mediterranean countries. In the third section, we present model specification and econometric methodology used in the analysis. In the fourth section, we present data and empirical results. At the end of this paper, we provide some concluding remarks and policy implications.

\section{An Overview of the Tourism Sector in Mediterranean Countries}

The Mediterranean consists of 29 tourist desti ations in Europe, Africa, and Middle East, and it shares a similar geography, climate, and in most cases a Mediterranean coastline, as well as historical and cultural links dating back to antiquity.We depict that the economic classification of destinations of the Mediterranean in Appendix B. Share of Mediterranean countries in the world is $31 \%$ for international tourist arrivals and $26 \%$ for international tourism receipts (Pierret, 2012).The Mediterranean region is one of the most important centers in the world because it is an attraction for international tourists. They aim to provide the diversity of tourism activities and to take these activities easily since Mediterranean countries are located in the same area. Moreover, the other key factors attracting international tourists to the region are the quality of tourism facilities and accessibility. Therefore, this region has a potential power on converting tourism earnings to economic gains. At present, the contribution of the tourism sector in the economy has reached significant amounts in the Mediterranean region (See. in Table 1). 
Table 1. The contribution of travel and tourism to economy in Mediterranean region

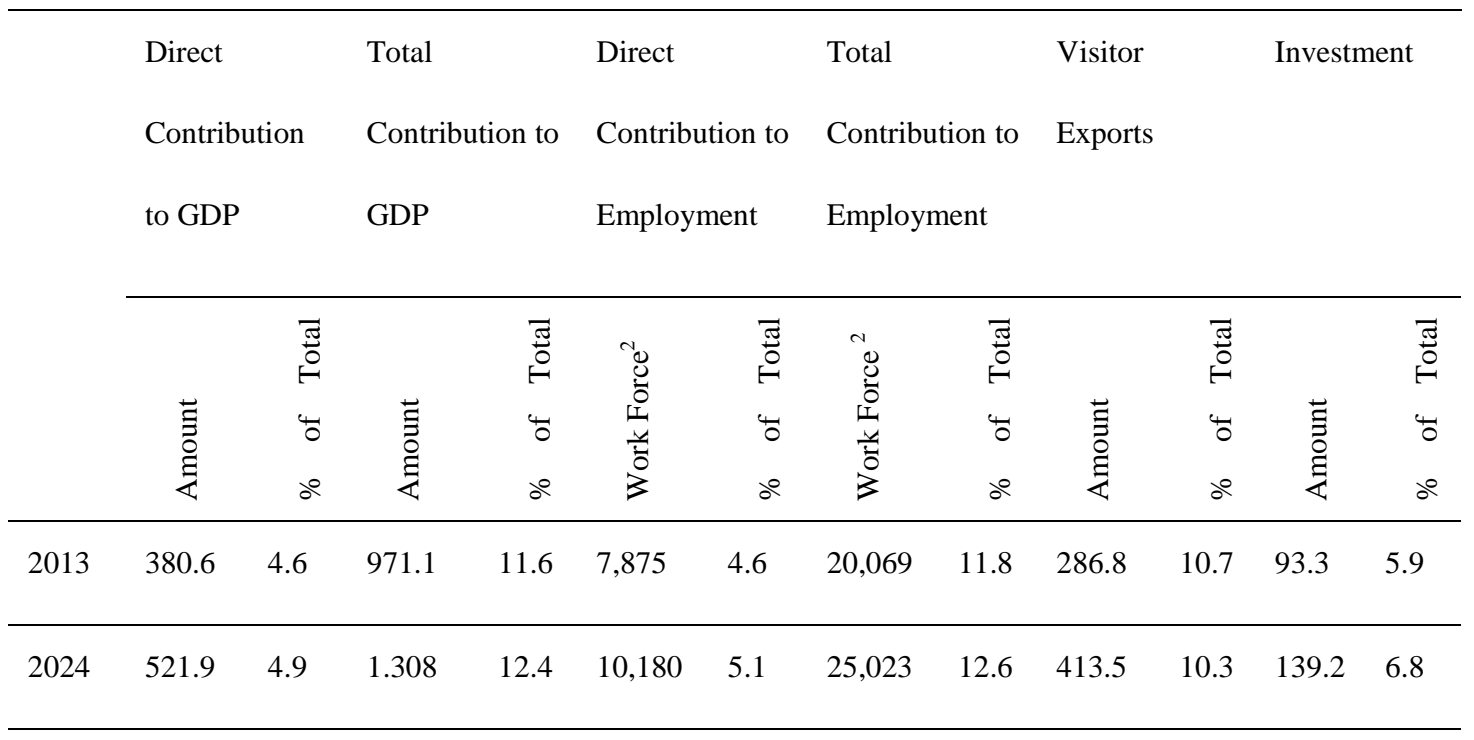

\section{${ }^{1} 2013$ constant prices and exchange rates ${ }^{2}$ '000 jobs}

Source: WTTC, 2014.

As shown in Table 1, the direct and total contribution of tourism to GDP, employment, exports, and investment are expected to rise in 2024, demonstrating that the economic importance of tourism sector will continue in the following years.According to WTTC (2014), the direct contribution of tourism and travel to GDP includes visitor exports, domestic travel and tourism expenditure, government 'individual' spending, and purchases by tourism providers, including imported goods. The total contribution of travel and tourism implies its wider effects on the economy and some factors in addition to direct contributions. They include travel and tourism investment spending, general government spending in support of general tourism activity, domestic purchases of goods and services by the sectors dealing directly with tourists, and the broader contribution to GDP and employment of spending by those who are directly or indirectly employed by travel and tourism. It should be noted that the contribution of Tourism and Travel to economy decreases in 2013 compared to 2008 (Figure 1). This declining trend may depend on decreasing tourism earnings from European countries due to the Global Crisis arising in 2008.

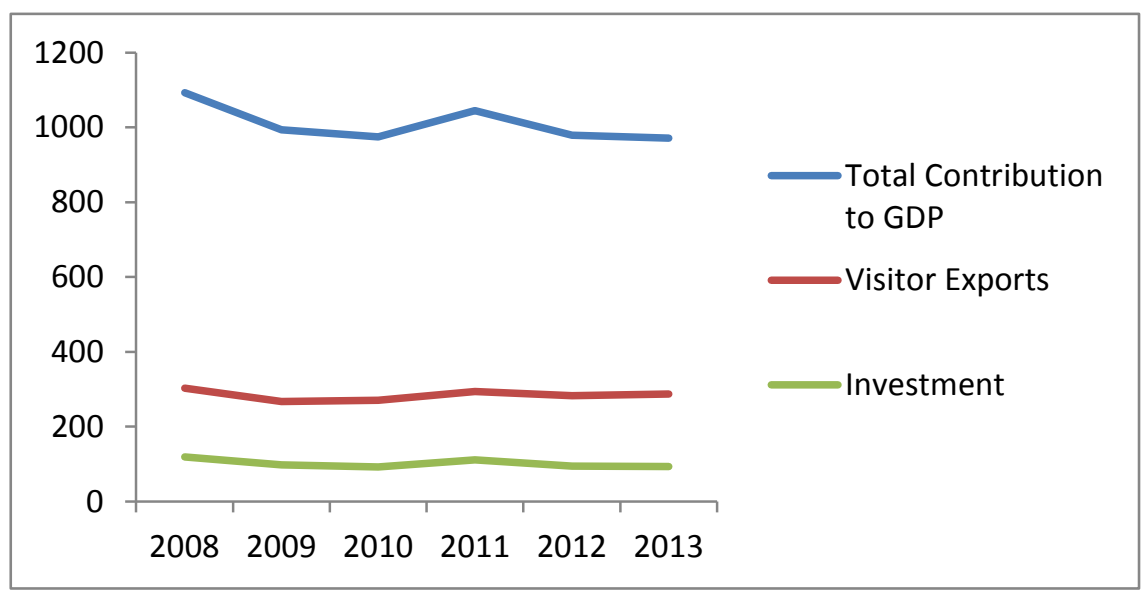

Figure 1. The economic contribution to GDP in Mediterranean region (Billion \$)

Source: WTTC, 2014. 
Table 2. The basic indicators concerning tourism sector and economy in Mediterranean countries



Tourist Arrivals in

the Region (\%)

The Share of 20
Tourism Receipts

Rate (1995-2010)

$(\%)$

\begin{tabular}{lllllllll}
\hline Real GDP per & 35,620 & 25,134 & 29,409 & 8,723 & 18,221 & 18,210 & 10,563 & 4,808 \\
capita (\$) (2013) & & & & & & & & \\
\hline Tourism Revenue & 66,064 & 67,608 & 46,190 & 34,863 & 16,188 & 16,221 & 9,721 & 4,632
\end{tabular}

(Billion\$) (2013)

\begin{tabular}{lllllllll}
\hline Number of Tourists & 84,726 & 60,661 & 47,704 & 37,795 & 17,920 & 8,097 & 10,955 & 6,898
\end{tabular}

(000) (2013)

Source: World Bank (2014); Pierret (2012)

In the Mediterranean region, it is remarkable that the top five destinations are France, Spain, Italy, Turkey, and Greece. All of these countries are located in the Europe region and received $76 \%$ and $74 \%$ of tourist arrivals and tourism receipts in the Region. Therefore, these countries are in competition for attracting tourists to their regions and have continued to allocate significant amounts of resources to induce their tourism sector. Table 2 shows the market share of the top five countries as well as other Mediterranean countries and gives information on the main economic indicators of these countries. When examining Table 2, it is concluded that a greater share of tourist arrivals does not mean a higher share of tourism receipts: France has a $26 \%$ share of tourist arrivals, but it receives only $20 \%$ of tourism receipts; Spain has a $23 \%$ share of tourism receipts although it has a $16 \%$ of tourist arrivals. Whether the countries have the capability of meeting the expectations of tourists, which mainly depends on providing sufficient facilities and services, may determine the differences between tourism receipts and tourist arrivals. Also, this difference can arise from the tourists with low income, who spend less than the tourists with high income. In this context, it is more desirable to increase tourism receipts than to increase tourism arrivals, and this is the main indicator showing the contribution of the tourism sector to the economy.

\section{Model Specification and Econometric Methodology}

\subsection{Theoretical Model}

Constructing the econometric model used in the study, we consider the standard Cobb-Douglas production function, with constant returns, within the neoclassical framework having Hicks-neutral technological process. This function can 
be shown as $Y_{t}=A_{t} K_{t}^{\alpha}$, where $Y_{t}$ is real per capita GDP; $A_{t}$ is total factor productivity; $K_{t}^{\alpha}$ is per worker capital services, and use extended form of this production function, following Jalil et al. (2013), Paci \& Marrocu (2014), Panahi et al. (2015), and Kumar et al. (2011).In the theoretical and empirical literature, Research and Development, human capital, and international trade could have a dual effect on productivity by stimulating innovation and facilitating technology transfer (Apergis, et al., 2008).In the studies analyzing the relationship between economic growth and tourism income, the growth model is constructed as a function of various variables. In these models, tourism receipts or tourist arrivals, taken as a main independent variable, and some control variables are used. In the empirical literature, for example, exchange rate variable (e.g. Po \& Huang, 2008; Brida et al., 2015; Balaguer \& Cantavella-Jorda, 2002; Dritsakis, 2004; Ongan \& Demiroz, 2005; Katırcığlu 2009a; Katırcığlu 2009b; Zortuk 2009; Belloumi, 2010; Tang, 2011; Holzner, 2011; Lee \& Chang, 2008; Payne \& Mervar,2010), physical or/and human capital (e.g. Paci \& Marrocu, 2014; Durbarry 2004; Cortes-Jimenez \& Pulina, 2010; Fayissa et al., 2008; Seetanah, 2011; Holzner, 2011; Capo et al., 2007; Ekanayake \& Long, 2012; Kumar \& Kumar, 2012); Gökoval, 2010; Saleh et al.,2015) and real exchange rate (Lee \& Chien, 2008; Panahi et al., 2015; Dritsakis, 2012; Brida \& Giuliani, 2013;Kasimati, 2011; Surugiu \& Surugiu ,2013; Tang, 2013) have been used. When reviewing the literature, we depict that import, export or openness variables have also been used in the models (e.g. Cortes-Jimenez et al., 2011; Santana-Gallego et al., 2011; Seetanah, 2011; Holzner, 2011). Due to considering these variables commonly used in the literature, we construct two growth models expressed as follows:

$$
\begin{aligned}
& G D P_{i t}=\beta_{0 i}+\beta_{1 i} R C P T_{i t}+\beta_{2 i} C A P_{i t}+\beta_{3 i} R E E R_{i t}+\beta_{4 i} E N R L_{i t}+\varepsilon_{i t} \\
& G D P_{i t}=\lambda_{0 i}+\lambda_{1 i} A R V L_{i t}+\lambda_{2 i} C A P_{i t}+\lambda_{3 i} R E E R_{i t}+\lambda_{4 i} E N R L_{i t}+\varepsilon_{i t}
\end{aligned}
$$

In Eq. 1 and Eq.2, the subscript $i(\mathrm{i}=1, \ldots \mathrm{N})$ denotes countries; the subscript $t$ denotes the time $(\mathrm{t}=1, \ldots, \mathrm{T})$; GDP denotes the natural logarithm of real GDP; RCPT is natural logarithm of tourism receipts; REER is real exchange rate; ENRL is school enrollment, ARVL is tourist arrivals, $\varepsilon_{t}$ is a stochastic error term. The reason for taking logarithms of the variables is to ease interpretations and to standardize measures (Merida \& Golpe, 2014). According to economic theory, it is expected that an increase in tourism income and investment spending contribute to GDP. In this context, the expected signs of $\beta_{1}$ and $\beta_{2}\left(\lambda_{2}\right)$ are positive, respectively. The similar effect on GDP is expected considering tourism arrivals, i.e. the expected sign of $\lambda_{1}$ is positive. The impact of real exchange rate on GDP is ambiguous because the depreciation of currency may increase export volume by increasing competitive power of a country, which contributes to economic growth. On the other hand, depreciation of currency causes an increase in inflation rate and interest rate as a policy reaction, which has an adverse effect on economic growth. Therefore, the expected sign of $\beta_{3}\left(\lambda_{3}\right)$ is positive or negative. Finally, it is expected that school enrollment has a positive effect on real GDP by increasing the marginal productivity of labor. Thus, the expected sign of $\beta_{4}\left(\lambda_{4}\right)$ is positive.

\subsection{Empirical Method}

In examining tourism income on economic growth, the first step is to determine the integrated orders of the variables. We use various panel unit root tests suggested by Levine, Lin \& Chu (2002) (LLC); Im, Pesaran \& Shin (2003) (IPS); Breitung (2000), and Harris-Tzavalis (1999). We refrain from giving details about these tests because these tests are commonly used and fairly standard in the literature. The details of these tests can be obtained from Baltagi (2008). Although LLC test and Breitung test assume a common unit root, the IPS test and ADF-Fisher test assume individual unit root process across the cross-sections. The null hypothesis of all tests is that time series under consideration are non-stationary. Applying ADF-Fisher test, we use inverse chi-squared, inverse normal, and inverse-logit transformation of p-values proposed by Choi (2001). It is worth noting that we subtract the cross-sectional averages from the series. According to Levin, Lin and Chu, the impact of cross-sectional dependence can be mitigated using this procedure.

After determining stationary properties of the series, if it is concluded that variables are integrated order one, we apply two cointegration techniques developed by Pedroni $(1999,2004)$ and Kao (1999) tests. Pedroni test is one of the residual-based types of panel cointegration tests and proposes panel cointegration test statistics that allow the parameters to vary across the individuals. Pedroni panel cointegration test requires estimating $y_{i t}=\alpha_{i}+\delta_{t}+$ $\beta_{1 i} x_{1 i t}+\beta_{2 i} x_{2 i t}+\cdots \beta_{k i} x_{k i t}+e_{i t}$ and the existence of cointegration relationship can be determined by taking the stationary of residual of this equation, $\left(e_{i t}\right)$ into consideration. Pedroni test statistics consists of panel variance $(v)$, panel rho, panel PP,panel ADF, group rho, group PP, and group ADF. The first four statistics are based on pooling along the within dimension of the panel and three are based on pooling along the between dimension of the panel. Pedroni test allows for heterogeneity among cross-sectional elements using idiosyncratic parameters and therefore it can be dealing with the heterogeneity problem, which is considered as a crucial problem in panel data models. It is worth noting that the assumption of cross-section independence gives rise to loss the power of the test. The second cointegration technique called Kao (1999) test uses DF and ADF tests and assumes cointegrating vectors are homogeneous. Applying Kao test, we estimate $y_{i t}=\alpha_{i}+\beta x_{i t}+u_{t}$ and then both tests are based on investigating residuals like Engle \& Granger (1987) cointegration test. 
Despite displaying the cointegration relationship, Pedroni cointegration test does not provide long-run coefficients. In this context, after applying cointegration test, next step is to estimate long-run coefficients in the model. In the empirical literature, several estimators have been used for this sake. The main estimators are Fully Modified OLS (FMOLS), dynamic OLS (DOLS), and Pooled Mean Group (PMG). In this paper, we consider FMOLS and DOLS estimators to examine the effect of tourism receipts and tourist arrivals on GDP in Mediterranean countries. The FMOLS and DOLS estimators, proposed by Kao \& Chiang (2000), are based on correcting the standard pooled OLS for serial correlation and endogeneity of regressors. Therefore, we obtain unbiased estimates of the cointegrating coefficients using these methods. DOLS method requires including lags and leads of the first differences of the regressors of the cointegrated regression. According to Kao \& Chiang (2000), DOLS estimator surpasses the FMOLS and OLS estimators.

\section{Data and Empirical Results}

\subsection{Data}

This paper covers a sample of nine Mediterranean countries: Bulgaria, Croatia, France, Greece, Israel, Italy, Macedonia, Portugal, and Spain. Yearly data on tourism receipts (RCPT), real GDP (GDP), number of arrivals (ARVL), real effective exchange rate (REER), school enrollment (ENRL), and capital formation (CAP) for these countries consist of the years between 1995 and 2013 and are obtained from World Bank (2014).The reason for selecting these countries and period is that data used in the model are obtained together for the investigated period for these countries. Moreover, the reasons for using the variables mentioned above are that they are used mostly in the literature, which is stressed in the previous section and that they reflect the theory on economic growth. The explanations of the variables and summary statistics are presented in Appendix C and Appendix D.

\subsection{Panel Unit Root Tests}

To analyze the effect of tourism receipts and tourist arrivals on GDP, we first examine the stationary properties of the data under consideration. Panel unit root tests are appliedin both levels and first differences for all variables, and p-values for the tests of the null hypothesis are reported in Table 3. High p-values indicate the data with the unit root, (i.e., non-stationary of the data) for LLC, IPS, Breitung, and Harris-Tzavalis panel root tests. The variables of RCPT, ARVL, CAP, and ENRL are stationary in the levels when considering LLC test, but nonstationary according to ADF Fisher, IPS, Breitung, and Harris-Tzavalis tests. Although GDP, dependent variable of the model, is stationary only in level for LLC test at 5\% level of significance, it is stationary in the first differences for other tests. In a similar manner, REER is stationary in the level for LLC and ADF-Fisher tests at 5\% level of the significance but nonstationary for IPS and Breitung tests at the same significance level. In general, the results of panel unit root tests indicate that the variables under consideration have the unit root, i.e., I(1).

Table 3. Panel Unit Root Tests

\begin{tabular}{|c|c|c|c|c|c|c|}
\hline Variables & $\begin{array}{l}\text { Levin, } \\
\text { Lin and Chu } \mathrm{t}^{*}\end{array}$ & $\begin{array}{l}\text { Im, } \\
\text { Pesaran and } \\
\text { Shin W-stat }\end{array}$ & $\begin{array}{l}\text { ADF- } \\
\text { Fisher } \chi^{2}\end{array}$ & $\begin{array}{l}\text { Breitung } \\
\text { t-stat. }\end{array}$ & $\begin{array}{l}\text { Harris- } \\
\text { Tzavalis }\end{array}$ & Result \\
\hline GDP & $-3.64 * * *$ & -0.99 & $27.88 *$ & 4.07 & 0.93 & $\mathrm{I}(1)$ \\
\hline$\Delta \mathrm{GDP}$ & $-4.43 * * *$ & $-2.91 * * *$ & $38.57 * * *$ & $-4.47 * * *$ & $0.49 * * *$ & \\
\hline RCPT & $-2.65 * * *$ & 0.74 & 12.39 & -0.66 & 0.89 & $\mathrm{I}(1)$ \\
\hline$\triangle \mathrm{RCPT}$ & $-10.41 * * *$ & $-8.33 * * *$ & $92.51 * * *$ & $-6.07 * * *$ & $0.02 * * *$ & \\
\hline ARVL & $-2.75 * * *$ & -0.38 & 22.45 & -1.25 & 0.82 & $\mathrm{I}(1)$ \\
\hline$\Delta \mathrm{ARVL}$ & $-5.51 * * *$ & $-6.27 * * *$ & $73.47 * * *$ & $-3.93 * * *$ & $0.04 * * *$ & \\
\hline CAP & $-3.40 * * *$ & -0.69 & 23.50 & 5.08 & 0.88 & $\mathrm{I}(1)$ \\
\hline$\triangle \mathrm{CAP}$ & $-5.91 * * *$ & $-4.07 * * *$ & $51.81 * * *$ & $-2.92 * * *$ & $0.13 * * *$ & \\
\hline ENRL & -0.19 & 2.64 & 7.80 & 1.67 & 0.98 & $\mathrm{I}(1)$ \\
\hline$\triangle \mathrm{ENRL}$ & $-6.16 * * *$ & $-5.41 * * *$ & $61.42 * * *$ & $-2.17 * *$ & $0.34 * * *$ & \\
\hline REER & $-2.67 * *$ & $-1.33 *$ & $30.59 * *$ & $-1.30 *$ & 0.86 & $\mathrm{I}(1)$ \\
\hline$\triangle \mathrm{REER}$ & $-6.36 * * *$ & $-6.43 * * *$ & $71.77 * * *$ & $-3.43 * * *$ & $0.08 * * *$ & \\
\hline
\end{tabular}

Note: All the variables except tertiary are expressed in natural logarithms. The individual intercept included in test regressions. Optimum lag lengths are automatically determined by Schwarz Information Criteria (SIC). The null hypothesis for the Levin, Lin and Chu, Im, Pesaran and Shin W-stat, and Harris-Tzavalis tests is the presence of a common unit root; for ADF-Fisher and Breitung tests the null is the presence of individual unit root.

\subsection{Panel Cointegration}

After examining panel unit-root tests, we apply Pedroni cointegration tests consisting of four within-group tests and three between-group ones. Panel cointegration tests are performed without trend and for demeaned panel. According to the results, the null hypothesis of no cointegration is rejected at 5 percent, and that of one cointegration vector is not 
rejected by four of the seven test statistics, which presents long-term relationship between variables.Thus, we conclude that a long-run relationship exist among GDP, RCPT, CAP, ENRL, and REER. The results are unchanged when the variable of ARVL is used instead of RCPT and thus indicate that tourism sector contribute to economic growth in the long-run. The similar results are obtained when applying Kao test: The null hypothesis of no cointegration is rejected at 5 percent and that of one cointegration vector is not rejected, which presents long-term relationship between variables, similar to Pedroni test. (See Table 4)

Table 4. Panel Cointegration Tests

\begin{tabular}{llllll}
\hline \multicolumn{7}{c}{ Pedroni Test } & & & & Kao Test \\
\hline \multirow{4}{*}{ Model-1 } & Panel v-statistic & 0.16 & Group rho-statistic & 2.42 & $-4.20^{* * *}$ \\
& Panel rho-statistic & 1.20 & Group PP-statistic & $-1.75^{* *}$ & \\
& Panel PP-statistic & $-0.94^{*}$ & Group ADF-statistic & $-2.32^{* *}$ & \\
& Panel ADF-statistic & & & & \\
& & & & & $-4.29^{* * *}$ \\
& & & & & \\
\multirow{5}{*}{ Model-2 } & Panel v-statistic & 1.33 & Group rho-statistic & 0.97 & \\
& Panel rho-statistic & -0.38 & Group PP-statistic & $-4.32^{* * *}$ & \\
& Panel PP-statistic & $-4.30^{* *}$ & Group ADF-statistic & $-3.06^{* * *}$ & \\
& Panel ADF-statistic & $-3.14^{* *}$ & & & \\
& & & & & \\
\hline
\end{tabular}

Note: Lag length is automatically selected on the basis of SBC. *,**, and *** indicate levels of statistical significance at $10 \%, 5 \%$, and $1 \%$, respectively.

\subsection{FMOLS and DOLS Estimators}

After finding the cointegration relationship between variables, we estimate the long-run coefficients of the variables. In this study, we use DOLS and FMOLS estimation methods because of biased OLS estimators stemming from endogenous of regressors. The long-run coefficients using DOLS and FMOLS method are reported in Table 5. Considering FMOLS estimators, we conclude that a 1\% increase in RCPT and ARVLincreases GDP $0.061 \%$ and 0.063 , respectively. This result indicates that the tourism sector has a positive effect on real GDP in the Mediterranean countries. When considering DOLS method, we find a positive contribution of RCPT and ARVL to GDP, which exhibits similar results to FMOLS method: 1\% increase in RCPTand ARVLyields a 0.085 and 0.233 increases in GDP, respectively.

Table 5. FMOLS and DOLS estimation results

\begin{tabular}{|c|c|c|c|c|c|}
\hline & & \multicolumn{2}{|c|}{ FMOLS } & \multicolumn{2}{|c|}{ DOLS } \\
\hline & & Coefficient & t statistic & Coefficient & t statistic \\
\hline \multirow{6}{*}{ Model-1 } & RCPT & 0.058 & $2.06^{* *}$ & 0.085 & $3.56 * * *$ \\
\hline & CAP & 0.389 & $8.81 * * *$ & 0.417 & $6.41 * * *$ \\
\hline & ENRL & 0.004 & $5.26 * * *$ & 0.003 & $2.50 * *$ \\
\hline & REER & -0.515 & $-5.04 * * *$ & -0.297 & $-1.99 *$ \\
\hline & & \multicolumn{2}{|c|}{ FMOLS } & \multicolumn{2}{|c|}{ DOLS } \\
\hline & & Coefficient & t statistic & Coefficient & t statistic \\
\hline \multirow{4}{*}{ Model-2 } & $\overline{A R V L}$ & 0.063 & $1.75^{*}$ & 0.233 & $3.46 * * *$ \\
\hline & CAP & 0.410 & $11.84 * * *$ & 0.359 & $5.76 * * *$ \\
\hline & ENRL & 0.005 & $7.64 * * *$ & 0.003 & $2.95 * * *$ \\
\hline & REER & -0.495 & $-5.59 * * *$ & $\begin{array}{l}-\quad 0.262 \\
\end{array}$ & -1.66 \\
\hline
\end{tabular}

Note: t-statistics are given in the parenthesis. ***, ** and * represent significant at $1 \%, 5 \%$ and $10 \%$ levels, respectively.

After estimating long-run coefficients, we determine the effects of the tourism sector on real GDP considering individual countries. Accordingly, country-specific coefficients are reported in Table 6 . The coefficient of RCPT is positive and statistically significant in all countries except Greece and Spain. This result indicates that the tourism sector has a positive effect on economic growth in Bulgaria, Croatia, France, Israel, Italy, Macedonia, and Portugal. Bulgaria is the country that has the highest coefficient among these countries; the coefficient of RCPT is 0.20 and 0.15 for FMOLS and DOLS, respectively. In general, the coefficients of other regressors have the expected signs and are also statistically significant. As regards the other main regressor, ARVL, we obtain similar results to the model with RCPT, i.e. model-2. 
The coefficient of ARVL is positive and statistically significant in Bulgaria, Israel, Italy, and Macedonia. Bulgaria is the country that has the highest coefficient among these countries; the coefficient of ARVL is 0.32 and 0.31 for FMOLS and DOLS, respectively. We do not disclose the coefficients of the control variables in detail to conserve space but, note that the variables of CAP and ENRL have positive signs and also are significant statistically. This evidence shows that human capital and physical capital are vital to economic growth in Mediterranean countries.

Table 6. Cointegration Estimates for Individual Countries

\begin{tabular}{|c|c|c|c|c|c|c|c|c|c|}
\hline & \multicolumn{4}{|c|}{ Model-1 } & \multicolumn{5}{|c|}{ Model-2 } \\
\hline & \multicolumn{2}{|c|}{ FMOLS } & \multicolumn{2}{|c|}{ DOLS } & & \multicolumn{2}{|c|}{ FMOLS } & \multicolumn{2}{|c|}{ DOLS } \\
\hline & Estimate & t-stat & Estimate & t-stat & & Estimate & t-stat & Estimate & t-stat \\
\hline \multicolumn{10}{|c|}{ Bulgaria } \\
\hline $\mathrm{RCPT}$ & 0.206 & $2.69 * *$ & 0.179 & $1.86^{*}$ & ARVL & 0.326 & $6.09 * * *$ & 0.310 & $4.41 * * *$ \\
\hline CAP & 0.227 & $2.02 *$ & 0.225 & $1.80^{*}$ & CAP & 0.172 & $2.83 * *$ & 0.138 & 1.71 \\
\hline ENRL & 0.010 & $3.02 * * *$ & 0.012 & $2.92 * *$ & ENRL & 0.005 & $2.17 * *$ & 0.006 & $1.90 *$ \\
\hline REER & -0.720 & $-2.25 * *$ & -0.692 & $-1.87 *$ & REER & -0.230 & -1.25 & -0.143 & -0.62 \\
\hline \multicolumn{10}{|c|}{$\underline{\text { Croatia }}$} \\
\hline RCPT & 0.071 & 0.89 & 0.092 & 0.95 & ARVL & 0.016 & 0.41 & 0.001 & 0.01 \\
\hline CAP & 0.286 & $2.55^{* *}$ & 0.237 & $1.83^{*}$ & CAP & 0.370 & $10.07 * * *$ & 0.358 & $7.26 * * *$ \\
\hline ENRL & 0.001 & 0.59 & 0.001 & 0.46 & ENRL & 0.002 & $2.08^{*}$ & 0.003 & $2.22 * *$ \\
\hline REER & 0.133 & 0.86 & 0.188 & 1.21 & REER & 0.140 & 0.75 & 0.177 & 0.70 \\
\hline \multicolumn{10}{|c|}{$\underline{\text { France }}$} \\
\hline $\mathrm{RCPT}$ & 0.100 & $2.53 * *$ & 0.094 & $2.03 *$ & ARVL & 0.213 & 1.03 & 0.160 & 0.58 \\
\hline CAP & 0.474 & $4.99 * * *$ & 0.481 & $4.47 * * *$ & CAP & 0.596 & $5.59 * * *$ & 0.613 & $4.25 * * *$ \\
\hline ENRL & 0.005 & $2.76^{* *}$ & 0.004 & $2.40 * *$ & ENRL & 0.005 & $1.83^{*}$ & 0.004 & 1.27 \\
\hline REER & -0.014 & -0.11 & 0.012 & 0.07 & REER & 0.286 & $2.19^{* *}$ & 0.299 & 1.69 \\
\hline \multicolumn{10}{|c|}{$\underline{\text { Greece }}$} \\
\hline RCPT & -0.057 & $-2.43 * *$ & -0.052 & $-1.90 *$ & ARVL & -0.108 & -1.75 & -0.113 & -1.31 \\
\hline CAP & 0.418 & $22.62 * * *$ & 0.412 & $19.14 * * *$ & CAP & 0.398 & $29.94 * * *$ & 0.394 & $22.15^{* * *}$ \\
\hline ENRL & 0.004 & $8.87 * * *$ & 0.004 & $7.19 * * *$ & ENRL & 0.004 & $7.51 * * *$ & 0.004 & $5.44 * * *$ \\
\hline REER & -0.238 & $-2.11 * *$ & -0.203 & -1.52 & REER & -0.219 & -1.69 & -0.222 & -1.23 \\
\hline \multicolumn{10}{|c|}{$\underline{\text { Israel }}$} \\
\hline RCPT & 0.158 & $4.53 * * *$ & 0.150 & $3.66 * * *$ & ARVL & 0.114 & $3.39 * * *$ & 0.110 & $2.74 * *$ \\
\hline CAP & 0.013 & 0.13 & 0.075 & 0.64 & CAP & -0.002 & -0.02 & 0.070 & 0.45 \\
\hline ENRL & 0.020 & $11.89 * * *$ & 0.0195 & $11.41 * * *$ & ENRL & 0.022 & $9.13 * * *$ & 0.021 & $8.16^{* * *}$ \\
\hline REER & -0.096 & -0.93 & -0.080 & -0.71 & REER & 0.015 & 0.10 & 0.021 & 0.13 \\
\hline \multicolumn{10}{|c|}{$\underline{\text { Italy }}$} \\
\hline $\mathrm{RCPT}$ & 0.012 & 0.44 & 0.010 & 0.37 & ARVL & 0.081 & $2.83 * *$ & 0.100 & $4.85^{* * *}$ \\
\hline CAP & 0.232 & $6.92 * * *$ & 0.265 & $6.81 * * *$ & CAP & 0.276 & $11.88 * * *$ & 0.299 & $15.87 * * *$ \\
\hline ENRL & 0.003 & $5.50 * * *$ & 0.003 & $4.49 * * *$ & ENRL & 0.002 & $3.85 * * *$ & 0.002 & $4.19 * * *$ \\
\hline REER & -0.265 & $-2.59 * *$ & -0.200 & $-2.18 * *$ & REER & -0.130 & -1.68 & -0.083 & -1.61 \\
\hline \multicolumn{10}{|c|}{$\underline{\text { Macedonia }}$} \\
\hline $\mathrm{RCPT}$ & 0.069 & $3.05 * * *$ & 0.064 & $2.66^{* *}$ & ARVL & 0.126 & $5.23 * * *$ & 0.130 & $5.17 * * *$ \\
\hline CAP & 0.238 & $3.76 * * *$ & 0.205 & $2.99 * * *$ & CAP & 0.043 & 0.73 & 0.024 & 0.40 \\
\hline ENRL & 0.006 & $2.50 * *$ & 0.007 & $2.64 * *$ & ENRL & 0.013 & $10.08 * * *$ & 0.013 & $9.21 * * *$ \\
\hline REER & -0.197 & -1.54 & -0.115 & -1.06 & REER & -0.182 & $-1.93 *$ & -0.160 & $-2.32 * *$ \\
\hline \multicolumn{10}{|c|}{$\underline{\text { Portugal }}$} \\
\hline $\mathrm{RCPT}$ & 0.043 & 1.55 & 0.043 & 1.06 & ARVL & 0.094 & 1.63 & 0.081 & 1.27 \\
\hline CAP & 0.320 & $15.44 * * *$ & 0.320 & $11.44 * * *$ & CAP & 0.316 & $13.50 * * *$ & 0.309 & $13.68 * * *$ \\
\hline ENRL & 0.005 & $6.88 * * *$ & 0.005 & $4.90 * * *$ & ENRL & 0.005 & $5.23 * * *$ & 0.005 & $5.01 * * *$ \\
\hline
\end{tabular}




\begin{tabular}{|c|c|c|c|c|c|c|c|c|c|}
\hline \multicolumn{9}{|c|}{$\underline{\text { Spain }}$} & $1.85^{*}$ \\
\hline $\mathrm{RCPT}$ & -0.075 & $-1.86^{*}$ & -0.089 & -1.36 & ARVL & -0.110 & -1.62 & -0.127 & -1.60 \\
\hline CAP & 0.373 & $21.42 * * *$ & 0.380 & $13.72 * * *$ & CAP & 0.387 & $13.22 * * *$ & 0.400 & $11.59 * * *$ \\
\hline ENRL & 0.007 & $13.40 * * *$ & 0.007 & $8.64 * * *$ & ENRL & 0.008 & $10.24 * * *$ & 0.008 & $8.89 * * *$ \\
\hline REER & 0.487 & $4.12 * * *$ & 0.502 & $2.68 * *$ & REER & 0.215 & $3.01 * * *$ & 0.203 & $2.49^{* * *}$ \\
\hline
\end{tabular}

Note:t-statistics are given in the parenthesis. $* * *, * *$ and $*$ represent significant at $1 \%, 5 \%$ and $10 \%$ levels, respectively.

Table 7 indicates the effect of the tourism sector on economic growth in the short-run using error-correction model. According to results, the coefficients of variables that used in the model-1 are positive and statistically significant except ENRL. Moreover, all coefficients of variables that are used in the model-2 are positive and statistically significant. In the short run, a $1 \%$ increase in RCPT increases GDP by 5\% and a $1 \%$ increase in ARVL increases GDP by $5 \%$. These results indicate that tourism sector contributes to economic growth in the short-run, as in the long-run. In general, the other variables used in the models have the expected signs in the short-run. For example, the coefficient of CAP variable is 0.20 and 0.22 for the model- 1 and model-2, respectively. These results show that capital formation is vital to economic growth in the short-run for Mediterranean countries. On the other hand, the coefficient of ENRL variable is not statistically significant at 5\% level. When considered together with long-run findings, this result indicates that the effect of human capital on economic growth may occur in the long-run rather than short-run. Indeed, this result is not surprising because the factors behind human capital such as $R \& D$ and education show their effects on human capital over time. The coefficient of REER is -0.22 and -0.18 , indicating that real appreciate of currency decreases economic growth in the short-run. Finally, one period lagged error correction term has a negative sign and statistically significant at the $5 \%$ level for both models $(-0.20$ and -0.20$)$. The error correction term measures the speed of adjustment to equilibrium following a shock to the system. Therefore, GDP returns to their equilibrium following shock in regressors. Moreover, the magnitude of the coefficient shows that the speed of adjustment to equilibrium is very fast.

Table 7. Short-Run Estimation Results

\begin{tabular}{|c|c|c|c|c|c|c|c|}
\hline & Variables & Coefficient & t-statistics & & Variables & Coefficient & t-statistics \\
\hline & constant & $0.009 * * *$ & 3.80 & & constant & $0.001 * * *$ & 3.98 \\
\hline & $\triangle \mathrm{RCPT}$ & $0.05 * * *$ & 4.65 & & $\triangle \mathrm{ARVL}$ & $0.05^{* * *}$ & 3.76 \\
\hline \multirow[t]{5}{*}{ Model-1 } & $\triangle \mathrm{CAP}$ & $0.20 * * *$ & 11.20 & Model-2 & $\triangle \mathrm{CAP}$ & $0.22^{* * *}$ & 12.03 \\
\hline & $\Delta$ ENRL & 0.001 & 1.53 & & $\triangle \mathrm{ENRL}$ & $0.001 *$ & 1.80 \\
\hline & $\triangle$ REER & $-0.22 * * *$ & -4.75 & & $\triangle \mathrm{REER}$ & $-0.18 * * *$ & -3.78 \\
\hline & $\mathrm{ECT}_{\mathrm{t}-1}$ & $-0.20 * * *$ & -5.69 & & $\mathrm{ECT}_{\mathrm{t}-1}$ & $-0.20 * * *$ & -5.76 \\
\hline & \multicolumn{4}{|c|}{$\bar{R}^{2}=0.57 ;$ F-statistics $=42.47 * * *$} & \multicolumn{3}{|c|}{$\bar{R}^{2}=0.55 ;$ F-statistics $=38.53 * * *$} \\
\hline
\end{tabular}

\section{Conclusion}

The Mediterranean region is one of the most attractive places in the world tourism since it has the advantages of providing the diversity of tourism activities. This region takes approximately $30 \%$ share of the world tourism sector. Therefore, the tourism sector has important contributions to the economy in Mediterranean countries, which is expected to increase in the following years. This paper aims to investigate the effect of the tourism sector on economic growth using the data for the period between the years of 1995 and 2013 for nine Mediterranean countries. For this purpose, we include the variables affecting economic growth to the model constructed in the study. We use panel cointegration technique to test long-relationship among the variables and estimate the long-run coefficients using FMOLS and DOLS. The cointegration test results indicate a long-run relationship among the variables. FMOLS and DOLS results show that 
tourism receipts and tourism arrivals have a positive effect on economic growth in the long-run. Furthermore, the results on individual effects show that tourism receipts and tourism arrivals contribute to economic growth in most of the Mediterranean countries, which are Bulgaria, Croatia, France, Israel, Italy, Macedonia, and Portugal. The empirical findings show that the tourism sector has crucial importance for economic growth in the Mediterranean countries. Moreover, human capital and physical capital contribute to economic growth. These results reveal that policy makers should consider the effects of policy decisions on the tourism sector and take measurements to increase tourism incomes.

\section{Acknowledgements}

I thank the editor and two anonymous reviewers for their helpful comments and suggestions.

This study was supported by The Scientific Research Projects Coordination Unit (BAPK) with project number 14.HIZ.DES.75.

\section{References}

Al-Mulali, U., Fereidouni, H. G., \& Lee, J. Y. M. (2014). Estimating the tourism-led growth hypothesis: A case study of the Middle East countries. Anatolia: An International Journal of Tourism and Hospitality Research, 25, 290-298.

Andriotis, K. (2002). Scale of hospitality firms and local economic development-evidence from Crete. Tourism Management, 23, 333-341.

Apergis, N., Economidou, C., \& Filippidis, I. (2008).Innovation, technology transfer and labor productivity linkages: Evidence from a panel of manufacturing industries. Review of World Economics, 144, 491-508.

Arslanturk, Y., \& Atan, S. (2012). Dynamic relation between economic growth, foreign exchange and tourism incomes: An econometric perspective on Turkey. Journal of Business, Economics and Finance, 1, 30-37.

Arslanturk, Y., Balcilar, M., \& Özdemir, Z. A. (2011). Time-varying linkages between tourism receipts and economic growth in a small open economy. Economic Modelling, 28, 664-671.

Aslan, A. (2014). Tourism development and economic growth in the Mediterranean countries: Evidence from panel Granger causality tests. Current Issues in Tourism, 1, 363-372.

Balaguer, J., \& Cantavella-Jorda, M. (2002). Tourism as a long-run economic growth factor: The Spanish case. Applied Economics, 34, 877-884.

Balassa, B. (1978). Exports and economic growth: Further evidence. Journal of Development Economics, 181-189.

Baltagi, B. H. (2008). Econometric analysis of panel data. (4th ed.). Wiley-Blackwell.

Belloumi, M. (2010). The relationship between tourism receipts, real effective exchange rate and economic growth in Tunisia. International Journal of Tourism Research, 12, 550-560.

Bouzahzah, M., \& El Menyari, Y. (2013).International tourism and economic growth: The case of Morocco and Tunisia. The Journal of North African Studies, 18, 592-607.

Breitung, J. (2000). The local power of some unit root tests for panel data. In Baltagi BH (ed), Nonstationary panels, panel cointegration, and dynamic panels, 161-178. Advances in Econometrics, 15.

Brida, J. G., \& Giuliani, D. (2013). Empirical assessment of the tourism-led growth hypothesis: The case of the TirolSu"dtirol-Trentino. Tourism Economics, 19, 745-760.

Brida, J. G., \& Risso, W. A. (2010). Tourism as a determinant of long-run economic growth. Journal of Policy Research in Tourism, Leisure and Events, 2, 14-28.

Brida, J. G., Lanzilotta, B., Pereyra, J. S., \& Pizzolon, F. (2015).A nonlinear approach to the tourism led growth hypothesis: The case of the MERCOSUR. Current Issues in Tourism, 18, 647-666.

Brida, J. G, Cortes-Jimenez, I., \&Pulina, M. (2014). Has the tourism-led growth hypothesis been validated? A literature review. Current Issues in Tourism. http://dx.doi.org/10.1080/13683500.2013.868414.

Capo, J., Riera Font, A., \& Rossello Nadal, J. (2007).Dutch disease in tourism economics: Evidence from the Balearics and the Canary Islands. Journal of Sustainable Tourism, 15, 615-627.

Choi, I. (2001). Unit root tests for panel data. Journal of International Money and Finance, 20, 249-272.

Chou, M. C. (2013). Does tourism development promote economic growth in transition countries? A panel data analysis. Economic Modelling, 33, 226-232.

Cortes-Jimenez, I. (2008). Which type of tourism matters to the regional economic growth? The cases of Spain and Italy. International Journal of Tourism Research, 10, 127-139. 
Cortes-Jimenez, I., \& Pulina, M. (2010). Inbound tourism and long-run economic growth. Current Issues in Tourism, 1, 61-74.

Cortes-Jimenez, I., Nowak, J., \& Sahli, M. (2011). Mass beach tourism and economic growth: Lessons from Tunisia. Tourism Economics, 17, 531-547.

Çaglayan, E., Sak, N., \& Karymshakov, K. (2012). Relationship between tourism and economic growth: A panel Granger causality approach. Asian Economic and Financial Review, 2, 591-602.

Dritsakis, N. (2004). Tourism as a long-run economic growth factor: An empirical investigation for Greece using causality analysis. Tourism Economics 10, 305-316.

Dritsakis, N. (2012). Tourism development and economic growth in seven Mediterranean countries: A panel data approach. Tourism Economics, 18, 801-816.

Durbarry, R. (2004). Tourism and economic growth: The case of Mauritius. Tourism Economics 10, 389-401.

Eeckels, B., Filis, G., \& Leon, C. (2012). Tourism income and economic growth in Greece: Empirical evidence from their cyclical components. Tourism Economics, 18, 817-834.

Ekanayake, E. M., \& Long, A. E. (2012). Tourism development and economic growth in developing countries. The International Journal of Business and Finance Research, 6, 51-63.

Engle, R. F., \& Granger, C. W. J. (1987). Co-integration and error correction: Representation, estimation, and testing. Econometrica, 55, 251-276.

Fayissa, B., Nsiah, C., \&Tadasse, B. (2008). Impact of tourism on economic growth and development in Africa. Tourism Economics, 14, 807-818.

Gökovalı, U., \& Bahar, O. (2006). Contribution of tourism to economic growth: A panel data approach. Anatolia: An International Journal of Tourism and Hospitality Research, 17, 155-167.

Gökvali, U. (2010). Contribution of tourism to economic growth in Turkey. Anatolia:An International Journal and Tourism and Hospitality Research, 21, 139-153.

Gunduz, L., \& Hatemi, J. A. (2005). Is the tourism-led growth hypothesis valid for Turkey? Applied Economics Letters, 12, 499-504.

Harris, R. D. F., \& Tzavalis, E. (1999). Inference for unit roots in dynamic panels where the time dimension is fixed. Journal of Econometrics, 91, 201-226.

Holzner, M. (2011). Tourism and economic development: The beach disease? Tourism Management, 32, $922-933$.

Husein, J., \& Kara, S. M. (2011). Research note: Re-examining the tourism-led growth hypothesis for Turkey. Tourism Economics, 17, 917-924.

Im, K. S., Pesaran, M. H., \& Shin, Y. (2003). Testing for unit roots in heterogeneous panels.Journal of Econometrics 115, 53-74.

Iwersen-Sioltsidis, S., \& Iwersen, A. (1996). Tourism and developing countries. Intereconomics, November/December, 301-306.

Jalil, A., Mahmood, T., \& Idress, M. (2013). Tourism-growth nexus in Pakistan: Evidence from ARDL bounds tests. Economic Modelling, 35, 185-191.

Kao, C. (1999). Spurious regression and residual-based tests for cointegration in panel data. Journal of Econometrics, 90, 1-44.

Kao, C., \& Chiang M. H. (2000). On the estimation and inference of a cointegrated regression in panel data. Advances in Econometrics, 15, 179-222.

Kaplan, M., \& Çelik, T. (2008). The impact of tourism on economic performance: The case of Turkey. The International Journal of Applied Economics and Finance, 2, 13-18.

Kasimati, E. (2011). Economic impact of tourism on Greece's economy: cointegration and causality analysis. International Research Journal of Finance and Economics, 79, 79-85.

Kasman, S. K., \& Kasman, A. (2004). Turizm gelirleri ve ekonomik büyüme arasındaki eşbütünleşme ve nedensellik ilişkisi, İktisat Işletme ve Finans, 120, 122-131.

Katırcıoglu, S. T. (2009a). Revising the tourism-led-growth hypothesis for Turkey using the bounds test and Johansen approach for cointegration. Tourism Management, 30, 17-20.

Katırcıoglu, S. T. (2009b).Testing the tourism-led growth hypothesis: The case of Malta.Acta Oeconomica, 59, $331-343$. 
Kızılgöl, Ö., \& Erbaykal, E. (2008). Türkiye'de turizm gelirleri ile ekonomik büyüme ilişkisi: Bir nedensellik analizi. Süleyman Demirel Üniversitesi İktisadi ve İdari Bilimler Fakültesi Dergisi, 13, 351-360.

Kumar, R. R., \& Kumar, R. (2012). Exploring the nexus between information and communications technology, tourism and growth in Fiji.Tourism Economics, 18, 359-371.

Kumar, R. R., Naidu, V., \& Kumar, R. (2011). Exploring the nexus between trade, visitor arrivals, remittances and Income in the Pacific: A study of Vanuatu. $A U D E$, 7, 199-218.

Lee, C. C., \& Chang, C. P. (2008). Tourism development and economic growth: A closer look to panels. Tourism Management, 29, 180-192.

Lee, C. C., \& Chien, M. S. (2008). Structural breaks, tourism development, and economic growth: Evidence from Taiwan. Mathematics and Computers in Simulation, 77, 358-368.

Lee, J. W., \& Brahmasrene, T. (2013). Investigating the influence of tourism on economic growth and carbon emissions: Evidence from panel analysis of the European Union.Tourism Management, 38, 69-76.

Levin, A., Lin, C. F., \& Chu, C. J. (2002). Unit root tests in panel data: Asymptotic and finite-sample properties. Journal of Econometrics, 108, 1-24.

Massidda, C., \& Mattana, P. (2013). A SVECM analysis of the relationship between international tourism arrivals, GDP and trade in Italy. Journal of Travel Research, 52, 93-105.

McKinnon, R. (1964). Foreign exchange constraint in economic development and efficient aid allocation. Economic Journal, 74, 388-409.

Merida, A., \& Golpe, A. A. (2014). Tourism-led growth revisited for Spain: Causality, business cycles and structural breaks. International Journal of Tourism Research.http://dx.doi.org/10.1002/jtr.2031.

Nissan, E., Galindo, M. A., \& Mendez, M. T. (2011). Relationship between tourism and economic growth. The Service Industries Journal, 31, 1567-1572.

Nowak, J. J., Sahli, M., \& Cortes-Jimenez, I. (2007). Tourism, capital good imports and economic growth: Theory and evidence for Spain. Tourism Economics, 13, 515-536.

Ongan, S., \& Demiroz, D. M. (2005). The contribution of tourism to the long-run Turkish economic growth. Ekonomický Časopis, 53, 880-894.

Öztürk, I., \& Acaravc1, A. (2009). On the causality between tourism growth and economic growth: empirical evidence from Turkey. Transylvanian Review of Administrative Sciences, 25, 73-81.

Paci, R., \& Marrocu, E. (2014). Tourism and regional growth in Europe. Papers in Regional Science, 93, 25-51.

Panahi, H., Mamipour, S., \& Nazari, K. (2015). Tourism and economic growth: A time-varying parameter approach. Anatolia: An International Journal of Tourism and Hospitality Research, 26, 173-185.

Pavlic, I., Svilokos, T., \& Tolic, M. S. (2015). Tourism, real effective exchange rate and economic growth: Empirical evidence for Croatia. International Journal of Tourism Research, 17, 282-291.

Payne, J. E., \& Mervar, A. (2010). The tourism-growth nexus in Croatia. Tourism Economics 16, 1089-1094.

Pedroni, P. (1999). Critical values for cointegration tests in heterogeneous panels with multiple regressors. Oxford Bulletin of Economics and Statistics, 61, 653-670.

Pedroni, P. (2004). Panel cointegration: Asymptotic and finite sample properties of pooled time series with an application to the PPP hypothesis. Econometric Theory, 20, 597-625.

Pierret, F. (2012). The Mediterranean - A tourism stronghold: Facts and figures. The future of Mediterranean tourism ( $6^{\text {th }}$ international conference on destination management) $16-17$

April2012,Djerba,Tunisia.http://dtxtq4w60xqpw.cloudfront.net/sites/all/files/pdf/01_frederic_pierret_0.pdf (accessed on 15 June 2015).

Po, W. C., \& Huang, B. N. (2008). Tourism development and economic growth - a nonlinear approach. Physica A 387, $5535-5542$.

Proença, S., \& Soukiazi, E. (2008). Tourism as an economic growth factor: A case study for Southern European countries. Tourism Economics, 14, 791-806.

Saleh, A. S., Assaf, A. G., Ihalanayake, R., \& Lung, S. (2015). A panel cointegration analysis of the impact of tourism on economic growth: Evidence from the Middle East region. International Journal of Tourism Research, 17, 209-220. 
Santana-Gallego, M., Ledesma-Rodríguez, F. J., \& Perez-Rodriguez, J. V. (2011). Tourism and trade in OECD countries. A dynamic heterogeneous panel data analysis. Empirical Economics, 41, 533-554.

Schubert, S. F., Brida, J. G., \& Risso, W. A. (2011). The impacts of international tourism demand on economic growth of small economies dependent on tourism. Tourism Management, 32, 377-385.

Seetanah, B. (2011). Assessing the dynamic economic impact of tourism for island economies.Annals of Tourism Research, 38, 291-308.

Surugiu, C., \& Surugiu, M. R. (2013). Is the tourism sector supportive of economic growth? Empirical evidence on Romanian tourism. Tourism Economics, 19, 115-132.

Tang, C. F. (2011). Is the tourism-led growth hypothesis valid for Malaysia? A view from disaggregated tourism markets. International Journal of Tourism Research, 13, 97-101.

Tang, C. F. (2013). Temporal Granger causality and the dynamic relationship between real tourism receipts, real income, real exchange rates in Malaysia. International Journal of Tourism Research, 15, 272-284.

Tang, C. F., \& Abosedra, S. (2014). Small sample evidence on the tourism led growth hypothesis in Lebanon. Current Issues in Tourism, 17, 234-246.

Tuğcu, C. T. (2014). Tourism and economic growth nexus revisited: A panel causality analysis for the case of the Mediterranean region. Tourism Management, 42, 207-212.

UNWTO. 2015. UNWTO World Tourism Barometer. January, Volume: 13.

http://dtxtq4w60xqpw.cloudfront.net/sites/all/files/pdf/unwto_barom15_01_january_excerpt_1.pdf (accessed on 15 June 2015).

Vanegas, M., \& Croes, R. R. (2003). Growth, development and tourism in a small economy: Evidence from Aruba. International Journal of Tourism, 5, 315-330.

World Bank. (2014). World Development Indicators.

http://databank.worldbank.org/data/reports.aspx?source=world-development-indicators (accessed on 20 January 2015).

WTO. (2014). World Trade Report 2014. https://www.wto.org/english/res_e/booksp_e/world_trade_report14_e.pdf (accessed on 15 June 2015).

WTTC. (2014). The Economic Impact of Travel \& Tourism 2014.

http://www.wttc.org/-/media/files/reports/economic\%20impact\%20research/regional\%20reports/world2014.pdf(ac cessed on 15 June 2015).

Zortuk, M. (2009). Economic impact of tourism on Turkey's economy: Evidence from cointegration tests. International Research Journal of Finance and Economics, 25, 231-239.

\section{Appendix A}

Previous studies investigating tourism economic growth nexus in Mediterranean countries

\begin{tabular}{|c|c|c|c|c|}
\hline Authors & TimeSpan & $\begin{array}{l}\text { Econometric } \\
\text { Methodology }\end{array}$ & Country & Result \\
\hline Balaguer & $1975-1997$ & Johansen & Spain & $\mathrm{T}=>\mathrm{Y}$ \\
\hline Cantavella-Jorda (2002). & & Cointegration & & \\
\hline Nowak et al. (2007) & $1960-2003$ & VECM & Spain & $\mathrm{T}=>\mathrm{Y}$ \\
\hline $\begin{array}{l}\text { Cortes-Jimenez \& Pulina } \\
\text { (2010) }\end{array}$ & $\begin{array}{l}\text { 1964-2000: Spain } \\
\text { 1954-2000: Italy }\end{array}$ & VECM & Spain-Italy & $\mathrm{T}=>\mathrm{Y}$ \\
\hline Cortes-Jimenes (2008) & $1990-2000$ & GMM & Spain-Italy & $\mathrm{T}=>\mathrm{Y}$ \\
\hline Brida \& Risso (2010) & $1980-2006$ & VECM & Italy & $\mathrm{T}=>\mathrm{Y}$ \\
\hline $\begin{array}{l}\text { Massidda } \quad \& \quad \text { Mattana } \\
\text { (2013) }\end{array}$ & $1987-2009$ & SVECM & Italy & $\mathrm{T}<=>\mathrm{Y}$ \\
\hline Dritsakis (2004) & $1960-2000$ & $\begin{array}{l}\text { Error correction } \\
\text { model }\end{array}$ & Greece & $\mathrm{T}=>\mathrm{Y}$ \\
\hline Kasimati (2011) & $1960-2010$ & $\begin{array}{l}\text { Johansen } \\
\text { Cointegration }\end{array}$ & Greece & No Relation \\
\hline
\end{tabular}




\begin{tabular}{|c|c|c|c|c|}
\hline Kaplan \& Çelik (2008) & $1963-2005$ & VAR model & Turkey & $\mathrm{T}=>\mathrm{Y}$ \\
\hline $\begin{array}{l}\text { Öztürk } \quad \& \quad \text { Acaravc1 } \\
(2009)\end{array}$ & $1987-2007$ & ARDL & Turkey & $\mathrm{T}=>\mathrm{Y}$ \\
\hline Gündüz \& Hatemi (2005) & $1963-2002$ & & Turkey & $\mathrm{T}=>\mathrm{Y}$ \\
\hline $\begin{array}{l}\text { Kasman \& Kasman } \\
(2004)\end{array}$ & $1963-2002$ & ARDL & Turkey & $\mathrm{T}=>\mathrm{Y}$ \\
\hline Panahi et al. (2015) & $1970-2011$ & $\begin{array}{lr}\text { Time Varying } & \\
\text { Parameter } & \text { and } \\
\text { Kalman } & \text { Filter } \\
\text { Approaches } & \end{array}$ & Turkey & $\mathrm{T}=>\mathrm{Y}$ \\
\hline $\begin{array}{l}\text { K1zılgöl \& Erbaykal } \\
(2008)\end{array}$ & & Toda-Yamamoto & Turkey & $\mathrm{Y}=>\mathrm{T}$ \\
\hline Katırcıoğlu (2009a) & $1960-2006$ & $\begin{array}{l}\text { Johansen } \\
\text { Cointegration }\end{array}$ & Turkey & No Relation \\
\hline Belloumi (2010) & 1970--2007 & $\begin{array}{l}\text { Johansen } \\
\text { Cointegration }\end{array}$ & Tunisia & $\mathrm{T}=>\mathrm{Y}$ \\
\hline $\begin{array}{l}\text { Bouzahzah \& El Menyari } \\
\text { (2013) }\end{array}$ & $1980-2010$ & $\begin{array}{l}\text { Johansen } \\
\text { Cointegration }\end{array}$ & Tunisia Morocco & $\begin{array}{l}\mathrm{T}=>\mathrm{Y} \\
\text { (Short-Run) } \\
\mathrm{Y=}=\mathrm{T} \\
\text { (Long-Run) }\end{array}$ \\
\hline Pavlic et al. (2015) & $1996-2013$ & VECM & Croatia & $\begin{array}{l}\mathrm{T}=>\mathrm{Y} \\
\text { (Long-run) }\end{array}$ \\
\hline Payne \&Mervar (2010) & 2000:01-2008:03 & VECM & Croatia & $\mathrm{Y}=>\mathrm{T}$ \\
\hline Gökovalı \& Bahar (2006) & $1987-2002$ & Panel Data & $\begin{array}{l}\text { Mediterranean } \\
\text { countries }\end{array}$ & $\mathrm{T}=>\mathrm{Y}$ \\
\hline $\begin{array}{l}\text { Lee\& } \quad \text { Brahmasrene } \\
(2013)\end{array}$ & $1988-2009$ & Panel Data & European Union & $\mathrm{T}=>\mathrm{Y}$ \\
\hline $\begin{array}{l}\text { Proença } \quad \text { \&Soukiazi } \\
(2008)\end{array}$ & $1990-2004$ & Panel Data & $\begin{array}{l}\text { Greece, Italy, } \\
\text { Portugal and Spain }\end{array}$ & $\mathrm{T}=>\mathrm{Y}$ \\
\hline Lee \& Chang (2008) & $1990-2002$ & Panel Data & $\begin{array}{l}\text { OECD and } \\
\text { non-OECD Countries }\end{array}$ & $\mathrm{T}=>\mathrm{Y}$ \\
\hline Aslan (2014) & $1995-2010$ & $\begin{array}{l}\text { Panel cointegration } \\
\text { and Granger } \\
\text { causality }\end{array}$ & $\begin{array}{l}12 \text { Mediterranean } \\
\text { countries }\end{array}$ & $\begin{array}{l}\mathrm{T} \Leftrightarrow=\mathrm{Y} \text { for } \\
\text { Portugal, Israel, } \\
\text { Turkey } \\
\mathrm{Y}=>\mathrm{T} \text { for Spain, } \\
\text { Italy, } \\
\text { Tunisia,Cyprus, } \\
\text { Croatia,Bulgaria, } \\
\text { Greece }\end{array}$ \\
\hline Dritsakis (2012) & $1980-2007$ & $\begin{array}{l}\text { Panel cointegration } \\
\text { and FMOLS }\end{array}$ & $\begin{array}{l}\text { Seven Mediterranean } \\
\text { countries: Spain, } \\
\text { France, Italy, } \\
\text { Greece, Turkey, } \\
\text { Cyprus and } \\
\text { Tunisia }\end{array}$ & $\mathrm{T}=>\mathrm{Y}$ \\
\hline
\end{tabular}




\section{Appendix B}

Economic classification of destinations of the Mediterranean

Advanced economy destinations

(all in Europe)

\section{Andorra}

Cyprus

France

Greece

Israel

Italy

Malta

Monaco

Portugal

San Marino

Slovenia

Spain

Source: Pierret (2012)

\section{Appendix C}

Sources and descriptions of data

\begin{tabular}{|c|c|c|c|}
\hline Variable & Definition & Description & Source \\
\hline GDP & Domestic & GDP (constant 2005 US\$) & World Bank \\
\hline & Product & $\begin{array}{l}\text { Data are expressed in natural } \\
\text { logarithmic form. }\end{array}$ & \\
\hline RCPT & Tourism Receipts & $\begin{array}{l}\text { International tourism receipts } \\
\text { (Current US \$). Data are expressed in } \\
\text { natural logarithmic form. }\end{array}$ & World Bank \\
\hline ARVL & Tourist Arrivals & $\begin{array}{l}\text { Number of arrivals. Data are } \\
\text { expressed in natural logarithmic } \\
\text { form. }\end{array}$ & World Bank \\
\hline CAP & Capital Formation & $\begin{array}{l}\text { Gross fixed capital formation } \\
\text { (constant } 2005 \text { US\$). Data are } \\
\text { expressed in natural logarithmic } \\
\text { form. }\end{array}$ & World Bank \\
\hline ENRL & School Enrollment & Gross enrollment ratio is the ratio of & World Bank \\
\hline
\end{tabular}


total enrollment.

REER Real Effective Real effective exchange rate index World Bank Exchange Rate $\quad(2010=100)$. Data are expressed in natural logarithmic form.

Appendix D

Summary statistics

\begin{tabular}{llllllc}
\hline & GDP & RCPT & ARVL & CAP & ENRL & REER \\
\hline Mean & 25.89099 & 22.63582 & 15.88914 & 24.33237 & 53.69394 & 4.555443 \\
Median & 25.97686 & 22.90538 & 15.88389 & 24.43102 & 53.76420 & 4.584100 \\
& & & & & & \\
Maximum & 28.48626 & 24.97794 & 18.25493 & 26.99248 & 116.6216 & 4.900076 \\
& & & & & & \\
Minimum & 22.28859 & 16.75995 & 11.50288 & 20.51019 & 18.50988 & 3.834826 \\
Std.Dev. & 1.892771 & 1.902268 & 1.773134 & 1.960057 & 17.93750 & 0.122096 \\
Observations & 171 & 171 & 171 & 171 & 171 & 171 \\
\hline
\end{tabular}

\section{(c) $)_{\mathrm{BY}}$}

This work is licensed under a Creative Commons Attribution 3.0 License. 